\title{
ANALISIS TINGKAT KESUKARAN DAN DAYA PEMBEDA PADA BUTIR TES SOAL UJIAN TENGAH SEMESTER BAHASA INDONESIA KELAS XII SMA NEGERI 7 MEDAN TAHUN PEMBELAJARAN 2016/2017
}

\author{
Oleh \\ Lenny Hartaty Lumbanraja \\ Dr. Syahnan Daulay, M.Pd.
}

Tujuan penelitian ini adalah untuk mendeskripsikan analisis tingkat kesukaran, daya pembeda dan distribusi tingkat kesulitan soal berdasarkan Taksonomi Bloom pada butir tes soal Ujian Tengah Semester.Adapun sampel sasaran uji coba dalam penelitian ini yaitu soal Ujian Tengah Semester bahasa Indonesia kelas XII SMA Negeri 7 Medan Tahun Pembelajaran 2016/2017. Metode penelitian dalam penelitian ini adalah penelitian deskriptif kuantitatif.Berdasarkan hasil pengolahan data yang didapat, hasil uji coba validitas menyatakan bahwa dari 25 soal Ujian Tengah Semester terdapat 20 soal yang valid atau sebanyak $(80 \%)$ dan 5 soal yang dinyatakan tidak valid atau sebanyak (20\%). Sedangkan hasil uji coba reliabilitas menyatakan bahwa soal merupakan soal yang reliabel dengan $\geq 0724,0,663$ maka soal yang diujikan memiliki reliabilitas yang tinggi. Setelah melaksanakan kedua uji coba tersebut maka disimpulkan bahwa butir soal masih belum memenuhi distribusi pembagian.

Hal ini dilihat dari tingkat kesukaran soal Ujian Tengah Semester yang dibuat oleh guru dan dilaksakan di SMA Negeri 7 Medan merupakan kategori sedang sebesar $60 \%$ dan daya pembeda soal dikategorikan ke dalam kategori cukup dan baik yang memiliki proporsi pembagian yang sama sebesar 36\%. Hasil pembagian distribusi tingkat kesulitan soal berdasarkan Taksonomi Bloom belum memenuhi kriteria, dikarenakan soal tersebut lebih banyak tergolong dalam kategori Pemahaman (C2) dan Aplikasi (C3) yaitu sebesar 40\%.

Kata kunci: analisis soal, tingkat kesukaran, daya pembeda, dan taksonomi Bloom

\section{PENDAHULUAN}

Peningkatan kualitas pendidikan dari tahun ke tahun terus dilakukan secara inovatif, baik dari sistem maupun teknik pengajaran oleh para guru di kelas. Peningkatan yang dapat dilakukan salah satunya dengan melakukan berbagai upaya dalam mengoptimalkan komponen-komponen pengajaran. Komponen dalam 
pembelajaran meliputi: tujuan pembelajaran, proses pembelajaran, dan evaluasi pembelajaran.Salah satu upaya dalam meningkatkan proses dan hasil belajar dapat dilakukan melalui sistem penilaian (evaluasi).

Melalui evaluasi, segala hal mengenai pembelajaran yang telah dilakukan dapat dilihat perkembangannya. Hal ini sejalan dengan pendapat (Arikunto dan Jabar, 2010) yang mengatakan bahwa, "Hasil evaluasi pembelajaran dapat digunakan untuk menentukan alternatif yang tepat dalam pengambilan keputusan untuk memperbaiki kinerja pada satuan pendidikan”. Salah satu syarat dalam melakukan evaluasi hasil belajar ialah isi tes harus mencakup aspek-aspek pencapaian yang akan dievaluasi.

Keberhasilan sebuah kegiatan evaluasi tidak terlepas dari alat evaluasi yang digunakan. Alat adalah sesuatu yang dapat digunakan untuk mempermudah seseorang untuk melaksanakan tugas atau mencapai tujuan secara lebih efektif dan efisien (Arikunto, $2006: 26$ ). Adapun alat evaluasi yang sering digunakan dalam proses belajar mengajar adalah tes. Hasil tes yang diperoleh akan menunjukkan baik tidaknya tes yang digunakan. Defenisi tes dalam (Arikunto, 2006 : 32) adalah serentetan pertanyaan atau latihan atau alat lain yang digunakan untuk mengukur keterampilan, pengetahuan, intelegensi, kemampuan atau bakat yang dimiliki oleh individu atau kelompok. Salah satu usaha untuk mengembangkan soal tes dengan kulitas yang baik adalah dengan melakukan analisis butir soal.

Analisis soal tes merupakan bentuk analisis hasil tes, yaitu analisis sehubungan dengan kualitas tes yang telah diselenggarakan guna mengali informasi mengenai kualitas tes yang telah diselenggarakan.Menurut (Azwar, 2000:142), yang mengatakan bahwa, "Analisis butir soal yang mencakup analisis tingkat kesukaran dan daya beda butir soal merupakan analisis klasik yang sekarang sudah jarang dilakukan”.Menurut pendapat (Susetyo, 2015 :184), yang mengatakan bahwa, tingkat kesukaran adalah seberapa sukar suatu butir dijawab oleh peserta tes atau responden".Sedangkan daya pembeda soal adalah kemampuan sesuatu soal untuk membedakan antara siswa yang pandai (berkemampuan tinggi) dengan siswa yang bodoh (berkemampuan rendah)(Martondang, 2009:111). 
Berdasarkan uraian di atas dapat disimpulkan bahwa keberhasilan sebuah evaluasi ditentukan oleh alat evaluasi yang digunakan.Untuk itu peneliti, menjadikan Tes Ujian Tengah semester sebagai objek kajian. Mengingat tes Ujian Tengah Semester merupakan tes buatan guru yang berguna untuk menentukan apakah tujuan pembelajaran telah tercapai.

Hal ini sejalan menurut pendapat(Arikunto, 2006 : 149) yang mengatakan bahwa kegunaan tes buatan guru adalah :

a. Untuk menentukan seberapa baik siswa telah menguasai bahan pelajaran yang diberikan dalam waktu kurun tertentu.

b. Untuk menentukan apakah sesuatu tujuan telah tercapai.

c. Untuk memperoleh suatu nilai.

Dengan dilakukan analisis butir soal, akan dapat diketahui kualitas tes yang diselenggarakan, dan akan membantu pengajar mengetahui apa saja hal yang berkaitan dengan pengembangan, penyusunan, dan pengunaan tes yang telah baik dan perlu dipertahankan.Dengan demikian, dilakukannya telaah kualitas butir soal dengan menggunakan analisis butir soal tingkat kesukaran dan daya pembeda maka dapat dideskripsikan kelayakan evaluasi yang telah dilakukan.

Berdasarkan uraian di atas, maka peneliti tertarik untuk melakukan penelitian tentang bagaimana tingkat kesulitan dan daya pembeda soal ujian tengah semester. Penelitian ini difokuskan pada (1) tingkat kesukaran butir soal Ujian Tengah Semester Bahasa Indonesia kelas XII di SMA Negeri 7 Medan Tahun Pembelajaran 2016/2017, (2) daya beda butir soal Ujian Tengah Semester Bahasa Indonesia di SMA Negeri 7 Medan Tahun Pembelajaran 2016/2017, (3) distribusi berdasarkan tingkat penyebaran soal sesuai dengan Taksonomi Bloom.

\section{METODE PENELITIAN}

Metode Penelitian merupakan hal yang penting untuk diperhatikan dalam sebuah penelitian. Hal ini disebabkan segala kegiatan yang dilakukan dalam sebuah penelitian dalam upaya menemukan dan membuktikan sesuatu sepenuhnya tergantung pada metode yang digunakan. Penelitian ini dilakukan dengan menggunakan metode deskriptif kuantitatif. Alasannya karena adanya deskripsi tentang kelayakan butir soal 
Ujian Tengah Semester tingkat SMA yang dapat dibuktikan dengan angka-angka. Pengukuran ini digunakan untuk menganalisis tingkat kesukaran dan daya pembeda butir soal Ujian Tengah Semester mata pelajaran Bahasa Indonesia tingkat SMA tahun pembelajaran 2016/2017.

\section{HASIL PENELITIAN DAN PEMBAHASAN}

\section{Hasil Penelitian}

\section{a. Tingkat Kesukaran Butir Soal}

Asumsi yang digunakan untuk memperoleh kualitas soal yang baik, di samping memenuhi validitas dan realibilitas, adalah keseimbangan dari tingkat kesulitan soal tersebut. Tetapi sebelum menganalisis soal berdasarkan tingkat kesukaran butir soal tersebut maka peneliti melakukan uji coba yang terdiri atas uji coba validitas dan realibilitas.

\section{Uji Validitas}

Karakteristik pertama dan memiliki peranan penting dalam instrumen evaluasi, yaitu karakteristik valid (validity) (Sukardi,2008:30). Suatu alat ukur dapat dikatakan valid apabila dapat mengukur dengan tepat dan benar. Oleh karena itu, soal yang baik adalah soal yang valid yaitu mempunyai dukungan yang besar terhadap skor total. Skor pada item menyebabkan skor total menjadi tinggi atau rendah. Sebuah itemmemiliki validitas yang tinggi jika skor pada item mempunyai kesejajaran dengan skor total. Kesejajaran ini dapat diartikan sebagai korelasi sehingga untuk mengetahui validitas itemdigunakan rumus korelasi (Arikunto,2006:76).Berdasarkan hasil penelitian tes evaluasi tersebut dapat dilihat bahwa dari 25 butir soal pilihan ganda yang dianalisis ditemukan 20 butir soal (80\%) dinyatakan valid, artinya soaltersebut dapat mengukur kemampuan yang diharapkan, dan 5 butir soal (20\%) dinyatakan tidak valid, artinya soal tersebut tidak dapat mengukur kemampuan yang diharapkan. 


\section{Uji Reliabilitas}

Hasil penelitian terhadap analisis reliabilitas soal berdasarkan patokan bahwa apabila $r_{11} \geq 0724,0,663$ maka soal yang diujikan memiliki reliabilitas yang tinggi tetapi apabilar $r_{11} \leq 0,724,0,663$ maka soal yang diujikan memiliki reliabilitas yang rendah atau tidak reliabel. Berdasarkan hasil analisis butir soal Ujian Tengah Semester kelas XII SMA Negeri 7 Medan diketahui bahwa soal tersebut mempunyai nilai $r_{11}$ lebih besar dari 0,297 yaitu sebesar 0,724, 0,663 sehingga soal tersebut memiliki reliabilitas yang tinggi atau reliabel.

Setelah melakukan uji coba validitas dan reliabilitas, maka analisis dilanjutkan ke karakteristik selanjutnya yaitu menganalisis tingkat kesukaran. Tingkat kesukaran adalah persentase jumlah siswa yang menjawab soal dengan benar atau salah (Arikunto,2006:207). Hasil analisis soal tersebut dapat dilihat bahwa tingkat kesukaran untuk soal pilihan ganda termasuk kriteria sedang, karena dari hasil analisis tersebut terdapat distribusi $40 \%$ soal berkriteria mudah, $60 \%$ soal berkriteria sedang, dan tidak ada soal yang berkriteria sukar.

\section{b. Daya Pembeda Butir Soal}

Berdasarkan hasil penelitian dapat dilihat bahwa soal Ujian Tengah Semester yang dipakai di SMA Negeri 7 Medan sebanyak 25 butir soal terdapat 6 butir soal (24\%) dengan kriteria jelek, 9 butir soal (36\%) dengan kriteria cukup, dan 9 butir soal (36\%) dengan kriteria baik serta 1 butir soal (4\%) dengan kriteria baik sekali.

\section{c. Distribusi Tingkat Kesulitan SoalSesuai Taksonomi Bloom}

Berdasarkan hasil penelitian terlihat jenjang soal aplikasi (C3) sejumlah 10 butir soal dengan presentase $40 \%$. Selanjutnya jenjang pemahaman (C2) sejumlah 10 butir soal dengan prosentase 40\% dan jenjang ingatan (C1) sejumlah 3 butir soal dengan presentase 12\%. Sedangkan untuk jenjang analisis (C4) sejumlah 2 butir soal dengan persentase 8\%, sintesis (C5), dan evaluasi 
(C6) tidak termuat dalam soal ulangan tersebut. Hasil analisis tersebut terlihat jenjang soal yang paling banyak adalah jenjang pemahaman (C2) dan aplikasi (C3) sejumlah 10 butir soal dengan presentase $40 \%$.

\section{Pembahasan Hasil Penelitian}

\section{a. Tingkat Kesukaran Butir Soal}

Perhitungan tingkat kesukaran soal adalah pengukuran seberapa besar derajat kesukaran suatu soal. Jika suatu soal memiliki tingkat kesukaran seimbang (proporsional), maka dapat dikatakan bahwa soal tersebut baik.Menurut (Arikunto, 2006:210), penentuan kelayakan soal perlu memperhatikan tujuan penggunaan soal, jika soal tes digunakan untuk memperoleh pencapaian hasil belajar siswa maka soal tes cenderung menggunakan soal yang tidak terlalu mudah dan tidak terlalu sulit. Untuk itu, dapat dikatakan bahwa untuk Ujian Tengah Semester yang bertujuan untuk mengukur pencapaian hasil belajar siswa, soal tes yang digunakan adalah soal yang tidak terlalu sukar dan tidak terlalu mudah.

Soal yang baik adalah soal yang tidak terlalu mudah atau tidak terlalu sukar.

Hal ini sejalan dengan pendapat (Arifin, 2009 : 270) yang menyatakan bahwa, untuk memperoleh prestasi belajar yang baik, sebaiknya proporsi antara tingkat kesukaran soal tersebar secara normal. Perhitungan proporsi tersebut dapat diatur sebagai berikut.

1) Soal sukar $25 \%$, soal sedang $50 \%$, soal mudah $25 \%$, atau

2) Soal sukar $20 \%$, soal sedang $60 \%$, soal mudah $20 \%$, atau

3) Soal sukar $15 \%$, soal sedang $70 \%$, soal mudah $15 \%$.

Agar perhitungan proporsi antara tingkat kesukaran soal tersebar secara normal maka terlebih dahulu peneliti harus menentukan kriteria penafsiran tingkat kesukaran soal dari hasil perhitungan yang dilakukan pada butir soal Ujian Tengah Semester kelas XII SMA Negeri 7 Medan dengan syarat yang dikemukakan oleh (Arifin, $2009: 270$ ) sebagai berikut.

Seperti yang dikemukakan oleh(Arifin, 2009 : 270) yang menyatakan bahwa, adapun kriteria penafsiran tingkat kesukaran soal adalah :

1) Jika jumlah persentase sampai dengan $27 \%$ termasuk mudah.

2) Jika jumlah persentase sampai dengan $28 \%-72 \%$ termasuk sedang.

3) Jika jumlah persentase dampai dengan $73 \%$ ke atas termasuk sukar. 
Dari hasil analisis tersebut terdapat $40 \%$ soal berkriteria mudah, $60 \%$ soal berkriteria sedang, dan tidak ada soal yang berkriteria sukar. Fakta tersebut didukung oleh pernyataan (Mudjijo, 2003 :62) yang mengatakan bahwa tingkat kesukaran suatu butir soal ditandai oleh presentase siswa yang menjawab dengan betul pada butir soal yang bersangkutan.

\section{b. Daya Pembeda Butir Soal}

Daya pembeda soal adalah kemampuan sesuatu soal untuk membedakan antara siswa yang pandai (berkemampuan tinggi) dengan siswa yang bodoh (berkemampuan rendah).

Hal ini sejalan dengan pendapat (Arikunto,2006:218)

Klasifikasi daya pembeda:

D : $0,00-0,20 \quad$ : jelek

D : $0,20-0,40 \quad$ : cukup

D : $0,40-0,70 \quad$ : baik

D : $0,70-1,00 \quad$ : baik sekali

Klasifikasi daya pembeda dengan D : 0,00 - 0,20 kategori jelek terdapat sebanyak 24\%, klasifikasi daya pembeda dengan D : 0,20 - 0,40 kategori cukup terdapat sebanyak 36\%, dan klasifikasi daya pembeda dengan D : 0,40 - 0,70 kategori baik terdapat sebanyak 36\% serta klasifikasi daya pembeda dengan D : 0,70-1,00 kategori baik sekali tidak terdapat pada soal Ujian Tengah Semester.

Hasil analisis tersebut dapat disimpulkan bahwa soal yang dibuat oleh guru mata pelajaran bahasa Indonesia dan dipakai pada Ujian Tengah Semester kelas XII SMA Negeri 7 Medan ditinjau dari daya pembeda soal untuk 25 butir soal pilihan ganda termasuk dalam kriteria cukup dengan proporsi (36\%) dan kriteria baik dengan proporsi (36\%). Berdasarkan hal tersebut dapat dikatakan bahwa soal pilihan ganda buatan guru cukup mampu membedakan antara siswa yang pandai dengan siswa yang kurang pandai. 


\section{c. Distribusi Tingkat Kesulitan Soal Berdasarkan Taksonomi Bloom}

(Kemendikbud, 2013 : 11), dalam diagram Taksonomi Bloom dijelaskan bahwa ada 5 tingkatan Taksonomi Bloom diantaranya ingatan (C1), pemahaman (C2), aplikasi (C3), analisis (C4), evaluasi (C5), dan mencipta (C6). sedangkan tingkatan sintesis tidak terdapat dalam diagram Taksonomi Bloom tersebut.

Pada tingkat SD terdapat 2 tingkatan yaitu ingatan (C1), dan pemahaman (C2), tingkat SMP terdapat 3 tingkatan yaitu ingatan $(\mathrm{C} 1)$, pemahaman $(\mathrm{C} 2)$, dan aplikasi (C3), tingkatan SMA terdapat 4 tingkatan yaitu ingatan (C1), pemahaman (C2), aplikasi (C3), dan analisis (C4), sedangkan pada tingkatan PT (Perguruan Tinggi), terdapat 5 tingkatan yaitu ingatan $(\mathrm{C} 1)$, pemahaman $(\mathrm{C} 2)$, aplikasi $(\mathrm{C} 3)$, analisis $(\mathrm{C} 4)$, evaluasi (C5) dan mencipta (C6).

Berdasarkan pada teori tersebut, distribusi soal Taksonomi BloomUjian Tengah Semester pada kelas XII SMA NEGERI 7 Medanbelum sesuai dengan distribusi tingkat kesulitan soal yang baik, karena jumlah persentase distribusi tingkat kesulitan soal yang paling banyak adalah jenjang pemahaman (C2) dan jenjang aplikasi (C2)sebanyak 40\%. Sesuai dengan tingkatan SMA ranah Taksonomi Bloom yang paling banyak adalah jenjang analisis tetapi pada soal Ujian Tengah Semester jenjang analisis (C4) hanya berjumlah 2 butir soal sebanyak $8 \%$.

\section{d. Analisis Butir Soal Keseluruhan}

Berdasarkan beberapa pertimbangan di atas, dapat ditentukan soal-soal yang dapat dipakai, direvisi atau dibuang. Soal yang dipakai jika memenuhi hal- hal sebagai berikut: kategori valid, daya beda baik, tingkat kesukaran sedang yaitu nomor soal 1,10,12,13,14,20,21,dan 22; kategori valid, daya beda cukup, tingkat kesukaran sedang yaitu nomor 23,24, dan 25. Soal-soal yang memenuhi kriteria secara keseluruhan ada 11 butir soal antara lain nomor 1,10,12,13,14,20,21,22,23,24,dan 25. Distribusi analisis butir soal yang dapat dipakai secara keseluruhan adalah $44 \%$.

$$
\text { Jumlah } \%=\frac{11}{25} \times 100 \%=44 \%
$$


Soal-soal yang dapat dipakai tetapi perlu direvisi yaitu: kategori valid, daya beda baik, tingkat kesukaran mudah atau sukar yaitu nomor 11 dan 19; kategori valid, daya beda jelek meskipun tingkat kesukaran sedang yaitu nomor 4; kategori tidak valid, daya beda baik, tingkat kesukaran sedang tidak ada nomor soal yang mewakilinya; kategori tidak valid, daya beda cukup, tingkat kesukaran sedang yaitu nomor 8 , dan 15 . Soal-soal yang memenuhi kriteria secara keseluruhan ada 5 butir soal antara lain nomor $4,8,11,15,19$. Distribusi analisis butir soal yang dapat dipakai secara keseluruhan adalah $24 \%$.

$$
\text { Jumlah } \%=\frac{5 \times 1}{25} 100 \%=20 \%
$$

Soal-soal yang sebaiknya dibuang yaitu: valid, daya beda jelek, tingkat kesukaran terlalu sukar atau terlalu mudah yaitu nomor 2, dan 3; tidak valid, daya beda cukup, tingkat kesukaran terlalu sukar atau terlalu mudah yaitu nomor $6,16,17$, dan 18 ; tidak valid, daya beda jelek, tingkat kesukaran sedang yaitu nomor 5 dan 9; tidak valid, daya beda jelek, tingkat kesukaran terlalu mudah atau terlalu sukar yaitu nomor 7. Soalsoal yang memenuhi kriteria secara keseluruhan ada 9 butir soal antara lain nomor $2,3,5,6,7,9,16,17,18$. Distribusi analisis butir soal yang dapat dipakai secara keseluruhan adalah $24 \%$.

$$
\text { Jumlah } \%=\frac{9 \times}{25} 100 \%=36 \%
$$

Soal-soal yang dapat dipakai di kelas XII SMA Negeri 7 Medan sebagai bank soal sebanyak 11 butir soal (44\%) dari 25 soal, soal yang dapat direvisi/diperbaiki sebanyak 5 butir soal (20\%) dan butir soal yang dibuang pada Ujian Tengah Semester sebanyak 9 butir soal (36\%).

\section{PENUTUP}

Berdasarkan hasil penelitian analisis tingkat kesukaran tersebut disimpulkan bahwa terdapat $40 \%$ soal berkriteria mudah, $60 \%$ soal berkriteria sedang, dan tidak ada soal yang berkriteria sukar. Hasil analisis tersebut dapat disimpulkan bahwa 25 soal pilihan ganda yang dibuat oleh guru mata pelajaran bahasa Indonesia dan dipakai pada 
Ujian Tengah Semester pada kelas XII SMA Negeri 7 Medan belum memenuhi pembagian proporsi tingkat kesukaran.

Hasil analisis daya pembeda tersebut dapat disimpulkan bahwa soal yang dibuat oleh guru mata pelajaran bahasa Indonesia dan dipakai pada Ujian Tengah Semester kelas XII SMA Negeri 7 Medan ditinjau dari daya pembeda soal untuk 25 butir soal pilihan ganda termasuk dalam kriteria cukup dengan proporsi (36\%) dan kriteria baik dengan proporsi (36\%).

Distribusi taksonomi Bloom Ujian Tengah Semester pada kelas XII SMA Negeri 7 Medan belum sesuai dengan distribusi tingkat kesulitan soal yang baik, karena jumlah persentase distribusi tingkat kesulitan soal yang paling banyak adalah jenjang pemahaman (C2) dan jenjang aplikasi (C2) sebanyak 40\%. Sesuai dengan tingkatan SMA ranah Taksonomi Bloom yang paling banyak adalah jenjang analisis tetapi pada soal Ujian Tengah Semester jenjang analisis (C4) hanya berjumlah sebanyak 8\%.

\section{DAFTAR PUSTAKA}

Arikunto, Suharsimi. 2006. Dasar-Dasar Evaluasi Pendidikan. Jakarta: Bumi Aksara.

Arikunto, Suharsimi dan Jabar, Cepi Safruddin abdul. 2010. Evaluasi Program Pendidikan: Pedoman Teoretis Praktis bagi Mahasiswa dan Praktisi Pendidikan Edisi Kedua. Jakarta: Bumi Aksara.

Arifin, Zainal. 2009. Evaluasi PembelajaranPrinsip, Teknik, Prosedur. Bandung: PT Remaja Rosdakarya.

Azwar, Saifudin. 2000. Tes Prestasi: Fungsi dan Pengembangan Pengukuran Prestasi Belajar, edisi 2. Yogyakarta: Pustaka Pelajar.

Kemendikbud. 2013. Implementasi Kurikulum 2013. Jakarta: Kemendikbud

Martondang,Zulkifli.2009. Pengantar Evaluasi. Medan: PPS Unimed.

Mudjijo. 2003. Tes Hasil Belajar. Jakarta: Bumi Aksara.

Sukardi.2008. Penilaian dan Pengukuran. Jakarta: Bumi Aksara.

Susetyo, Budi. 2015. Prosedur Penyusunan \& Analisis Tes: Untuk Penilaian Hail Belajar Bidang Kognitif. Bandung : Refika Aditama. 